\title{
Bibliometrics Analysis of English Teaching Method in Covid-19 Pandemic
}

Bungsudi, Masters D egree of English Education D epartment, Universitas Lampung, Indonesia, bungsudi@gmail.com

Fenny Thresia, Universitas Muhammadiyah Metro, Indonesia

fenny.thresia@yahoo.com

\begin{abstract}
Covid-19 requires educators to innovate using the adaptive English teaching method. Various researchers have researched English teaching methods to solve the learning process in the Covid-19 pandemic. Therefore multiple studies need to be compiled into one discussion to produce information for the subsequent researchers about future opportunities. This study conducts the Bibliometrics Analysis method to analyze the citation of research articles. The study population adopts article primer data of English teaching method in Covid-19 pandemic by searching through G oogle scholar with the key "English teaching method in Covid-19 pandemic" using Publish or Perish (PoP) software in D ecember 2020. Based on the initial data search using the Publish or Perish (PoP) application, there were 989 articles. After screening the suitability of the topic, 63 articles were obtained, which became data to discuss. Data mapping results using the VOSViewer Software show the research trend is in the keyword that appears the most of sixty-three articles such as student, pandemic Covid, teacher, education, teaching, and EFL Teacher. Therefore, the following research potential uses other teaching media of the keyword summary presented by VOSViewer.
\end{abstract}

Keywords: English teaching method, covid-19 pandemic, bibliometrics

Published: 2021-09-26

Doi: https:/ / doi.org/ 10.24127/ sociometry.v1i1.1343

\section{How to Cite:}

Bungsudi, B., \& Thresia, F. (2021). Bibliometrics Analysis of English Teaching Method in Covid-19

Pandemic. Sociometry Journal of Social Science, Art and Humanity, 1(1).

https:/ / doi.org/ 10.24127/ sociometry.v1i1.1343

Issue: Vol 1 No 1 (2021)

Section: Articles

(c) (7)

Copyright (c) 2021 Sociometry Journal of Social Science, Art and Humanity

This work is licensed under a Creative Commons Attribution 4.0 International License. 


\section{INTRODUCTION}

The Corona Virus Disease (Covid-19) Pandemic has spread globally in whole countries after appearing in Wuhan, China, in 2019. World Health O rganization (WHO) has declared the Covid-19 as pandemic on March 13, 2020. Because its spreading is relatively fast and has been touching many people globally, many countries release the rule to work or study from home to prevent the more spread. The study from home becomes an alternative to save the students from being infected. It also brings a way to study the difference where the educator must give instructions virtually.

Many researchers have developed various instructional methods in Covid-19 Pandemic to find the solution to give the best method to facilitate the learning process. One of them is the English Teaching Method. (Patel et al., 2008) stated that the English teaching method is the entire process of planning, selecting, and assessing English language material, and the teaching process considers the students' conditions to be taught. This teaching method is applied in teaching both in class and outside the classroom that is planned, structured, and adapts to the teaching approach, goals, which have been predetermined to improve student learning experiences (Edissherashvili, 2014); (Munzaki et al., 2017); (Yildizlar, 2013). Besides, various English teaching methods need to be applied in learning other than the lecture teaching method (Mahesh D eelip et al., 2016). We know that, in general, the English teaching method always focuses on two sides. Namely the approach to language use such as speaking and understanding text, podcasts, and oral. Another concern is language analysis, namely, understanding the grammar rules in English (Murcia, 2002).

The number of researches that discuss the English Teaching Method in Covid-19 Pandemic needs to map to find the field of articles. The way to map the English Teaching Method area in the Covid-19 Pandemic is by using bibliometrics analysis. Bibliometric analysis is a method for analyzing, evaluating bibliographic data available in research journals. that can be presented quantitatively, mathematically, and statistically, which can later be used as reference material for scientific or research development trends. (Y u et al., 2019); (Ellegaard, 2018); (Ardito, L. et al., 2019). Bibliometrics is responsible for checking scientific article references, indexing article citations, grouping related scientific articles, and mapping journals' scientific fields. This bibliometrics will provide an overview of the characteristics of changes and developments in research on current trends and future trends, making it easier for researchers to plan and conduct their research (Basuki, 2002); (Nobre \& Tavares, 2017).

From the theories above, this study aims to expose: (1) The article number of English Teaching Method in Covid-19 Pandemic; (2) The number of joumals and the publisher published articles of English Teaching Method in Covid-19 Pandemic; (3) The research trend of English Teaching Method in Covid-19 Pandemic; (4) The next topic will have the potential to study.

\section{METHOD}

This study conducts the Bibliometrics Analysis method to analyze the citation of the article. The study population adopts article primer data of English Teaching Method in Covid-19 Pandemic by searching through Google scholar with the key "English Teaching Method in Covid-19 Pandemic" using Publish or Perish (PoP) software in D ecember 2020. There are 989 articles provided in the Software. The processed article sample is some articles that focus on English Teaching Method in Covid-19 Pandemic. Then, data processing will use other soft wares: Microsoft Excel, Mendeley, and VO Sviewer.

This study has four steps to get the English teaching method data in the Covid-19 Pandemic. The first step is initial searching by using Publish or Perish Software, were found 989 articles. The second step is filtering by analyzing the articles, which are categorized as citations or books. The third step is filtering the articles which are not required as an article of the English Teaching Method in Covid-19 Pandemic. The last step is data processing, which is obtained after filtering in steps two and three. The following is the data filtering procession: 
Table 1. D ata purification of 989 Articles

\begin{tabular}{clc}
\hline No & \multicolumn{1}{c}{ Journal Search Screening } & $\begin{array}{c}\text { The Number of } \\
\text { Articles }\end{array}$ \\
\hline 1 & The number of Initial Search Journal & 989 \\
\hline 2 & Unidentified/ citation link/ book & 10 \\
\hline 3 & Not Required as English Teaching Method in Covid-19 Pandemic & 916 \\
\hline 4 & English Teaching Method in Covid-19 Pandemic & 63 \\
\hline
\end{tabular}

Table 2. Initial D ata Metrics and D ata Purification in Publish or Perish (PoP) Software

\begin{tabular}{lcc}
\hline \multicolumn{1}{c}{ Metric data } & The Initial Search & The End Search D ata \\
\hline Publication Y ears & $2019-2020$ & $2019-2020$ \\
\hline Citation Y ears & $1(2019-2020)$ & $1(2019-2020)$ \\
\hline Papers & 989 & 63 \\
\hline Citations & 11320 & 147 \\
\hline Cites/ year & 11320.00 & 147.00 \\
\hline Cites/ paper & 11.45 & 2.33 \\
\hline Author/ paper & 2.82 & 1.94 \\
\hline H-index & 42 & 6 \\
\hline G-index & 90 & 10 \\
\hline hI, norm & 29 & 3 \\
\hline hI,annual & 29.00 & 3.00 \\
\hline Paper with ACC & $>=1,2,5,10,20: 760,652,341,179,93$ & $>=1,2,5,10,20: 35,24,7,3,2$ \\
\hline Year_first & 2019 & 2019 \\
\hline Year_last & 2020 & 2020
\end{tabular}

\section{RESULT AND DISCUSSION}

Article Distribution of English Teaching Method in Covid-19 Pandemic: Based on the Publication Year

Based on the obtained data, the distribution of sixty-three articles of English Teaching Method in Covid-19 Pandemic is published in 2019 and 2020. The majority of articles are published in 2020 that hold fifty-two articles. While remainder, amounting to eleven articles, are published in 2019. The following is the table 4 list of articles published each year:

Table 4. List of articles published each year

\begin{tabular}{ccc}
\hline Publication Year & Number of Articles & Percentage \\
\hline $\mathbf{2 0 1 9}$ & 11 & $17,46 \%$ \\
\hline $\mathbf{2 0 2 0}$ & 52 & $82,54 \%$ \\
\hline Total & $\mathbf{6 3}$ & $\mathbf{1 0 0 \%}$
\end{tabular}

The data above shows that the English Teaching Method's research trend in the Covid-19 Pandemic increases. The increasing trend is significant enough to increase by 60\% from publication year in 2019 to 2020.

\section{Article Distribution of English Teaching Method in Covid-19 Pandemic: Based on the Quartile at SCImago}

After searching scientific articles through Publish or Perish (PoP) Software on database Google Scholar by using the keyword "English Teaching Method in Covid-19 Pandemic", only sixty-three articles relate to the 
context. The analysis uses the platform SCImago to know how many articles are included in Q uartile 1-4. Based on the data, seven articles are available in SCImago, where two articles are required in Q uartile $1(3,2 \%)$, five articles are required in Quartile 4 (7,9\%), and fifty-six are not available in SCImago (88,9\%). Below are table 3 and chart 1 of the number of articles published by the Scimago quartile.

Table 3. The distribution of the number of articles published by the Scimago quartile

\begin{tabular}{clcc}
\hline No & \multicolumn{1}{c}{ Rank } & Number of Articles & Percentage \\
\hline 1 & Q uartile 1 & 2 & $3,2 \%$ \\
\hline 2 & Q uartile 4 & 5 & $7,9 \%$ \\
\hline 3 & Not D etected at SCImago & 56 & $88,9 \%$ \\
\hline \multicolumn{2}{r}{ Total } & 63 & $100 \%$ \\
\hline
\end{tabular}

Chart 1. The distribution of the number of articles published by the Scimago quartile

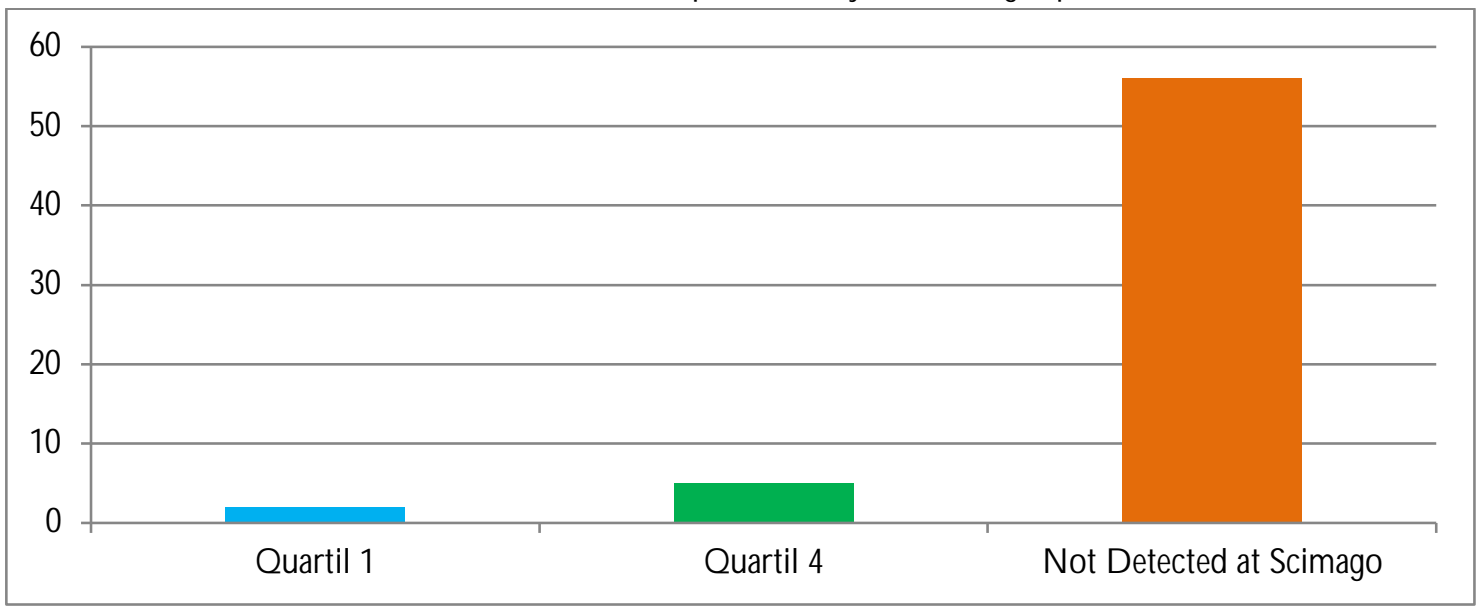

\section{Article Distribution of English Teaching Method in Covid-19 Pandemic: Based on Country of Publisher}

The sixty-three articles which discuss English Teaching Method in Covid-19 Pandemics are published from various countries. Eleven countries have published sixty-three articles in this study. The United States is a country that contributes to the most significant number of articles. The United States has published forty-four articles of sixty-three articles. Then, Indonesia is the second country that bestows the most significant number of articles with seven articles. G ermany, Turkey, the United Kingdom, and Switzerland are countries that each affords two articles.

Meanwhile, China, Malaysia, Pakistan, and Thailand are countries that place the last position. Each of them assigns one article. The following are table 6 and chart 3 of the country that publish English Teaching Method in Covid-19 Pandemic:

Table 6. List of Countries that Publish English Teaching Method in Covid-19 Pandemic

\begin{tabular}{clcc}
\hline No & \multicolumn{1}{c}{ Country of Publisher } & Number of Articles & Percentage \\
\hline 1 & United States & 44 & $69,84 \%$ \\
\hline 2 & Indonesia & 7 & $11,11 \%$ \\
\hline 3 & Germany & 2 & $3,17 \%$ \\
\hline 4 & Turkey & 2 & $3,17 \%$ \\
\hline 5 & United Kingdom & 2 & $3,17 \%$ \\
\hline 6 & Switzerland & 2 & $3,17 \%$ \\
\hline
\end{tabular}




\begin{tabular}{|c|c|c|c|}
\hline No & Country of Publisher & Number of Articles & Percentage \\
\hline 7 & China & 1 & $1,59 \%$ \\
\hline 8 & Malaysia & 1 & $1,59 \%$ \\
\hline 9 & Pakistan & 1 & $1,59 \%$ \\
\hline 10 & Thailand & 1 & $1,59 \%$ \\
\hline & Total & 63 & $100 \%$ \\
\hline
\end{tabular}

Chart 3. The Chart of Country that Publishes English Teaching Method in Covid-19 Pandemic

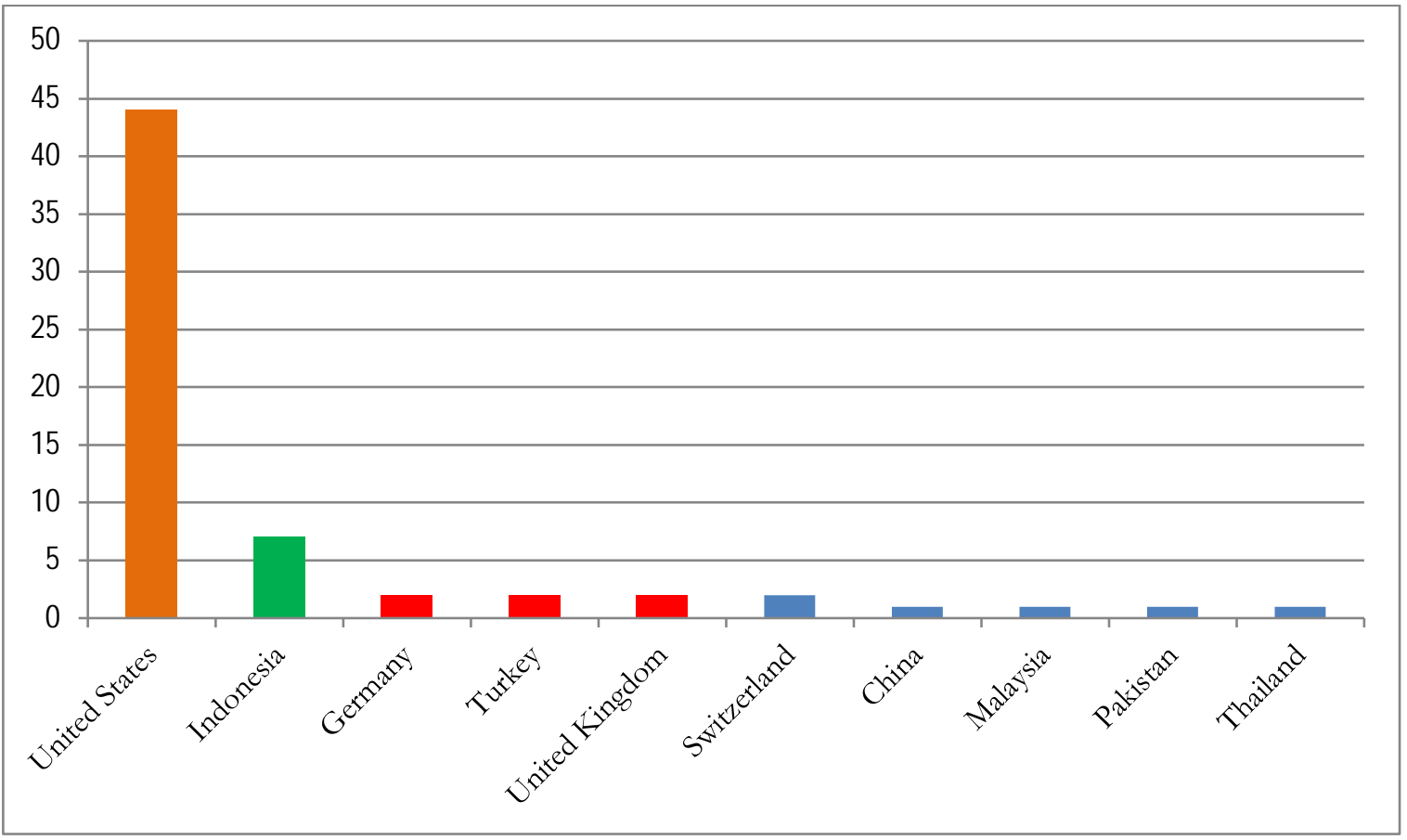

\section{Article Distribution of English Teaching Method in Covid-19 Pandemic: Based on Publisher}

While the point of view of analyzing the number of publishers, twenty-six reputed publishers have published sixty-three articles discussed in this study. Among them, the publisher that dominates the most significant number is IGI Global. IG I Global has published thirty-five articles of sixty-three articles. It takes half of the number of articles discussed in this study, equivalent to $55.56 \%$. It is then followed by the American Council on the Teaching of Foreign Languages as the publisher that is in second-largest number. These two articles were published by the publisher of the American Council on the Teaching of Foreign Languages, which is equivalent to $3.17 \%$.

Furthermore, there are Education Resources Information Center Publisher and Researchgate publishers in third and fourth place with the same number of articles. Meanwhile, the remaining twenty-two publishers only publish one article in this discussion. The followings are table 5, list, and chart 2 of publishers. 
Table 5. List of Publishers who have published articles of English Teaching Method in Covid-19 Pandemic

\begin{tabular}{|c|c|c|c|}
\hline No & Publisher & Number of Articles & Percentage \\
\hline 1 & IG I Global & 35 & $55,56 \%$ \\
\hline 2 & American Council on the Teaching of Foreign Languages & 2 & $3,17 \%$ \\
\hline 3 & Education Resources Information Center & 2 & $3,17 \%$ \\
\hline 4 & Researchgate & 2 & $3,17 \%$ \\
\hline 5 & Academia & 1 & $1,59 \%$ \\
\hline 6 & Ajhssr & 1 & $1,59 \%$ \\
\hline 7 & American Linguist Association & 1 & $1,59 \%$ \\
\hline 8 & davidpublisher & 1 & $1,59 \%$ \\
\hline 9 & D enpasar Institute & 1 & $1,59 \%$ \\
\hline 10 & D ergiPark & 1 & $1,59 \%$ \\
\hline 11 & Emerald Group Publishing & 1 & $1,59 \%$ \\
\hline 12 & IAIN Kediri & 1 & $1,59 \%$ \\
\hline 13 & Mdpi & 1 & $1,59 \%$ \\
\hline 14 & Politeknik Negeri Bali & 1 & $1,59 \%$ \\
\hline 15 & Sage Publishing & 1 & $1,59 \%$ \\
\hline 16 & SocArXiv Papers & 1 & $1,59 \%$ \\
\hline 17 & Southwest Jiaotong University & 1 & $1,59 \%$ \\
\hline 18 & Springer & 1 & $1,59 \%$ \\
\hline 19 & Tarih Kültür ve Sanat Araştırmalan D ergisi & 1 & $1,59 \%$ \\
\hline 20 & Thaijo & 1 & $1,59 \%$ \\
\hline 21 & Universitas Islam Sultan Agung & 1 & $1,59 \%$ \\
\hline 22 & Universitas Mahasaraswati D enpasar & 1 & $1,59 \%$ \\
\hline 23 & Universitas Negeri Padang & 1 & $1,59 \%$ \\
\hline 24 & Universitas Syiah Kuala & 1 & $1,59 \%$ \\
\hline 25 & Universiti Pendidikan Sultan Idris & 1 & $1,59 \%$ \\
\hline \multirow[t]{2}{*}{26} & University of Management and Technology & 1 & $1,59 \%$ \\
\hline & Total & 63 & $100 \%$ \\
\hline
\end{tabular}


Chart 2. The Chart of Publishers, which have published articles on English Teaching Method in Covid-19 Pandemic

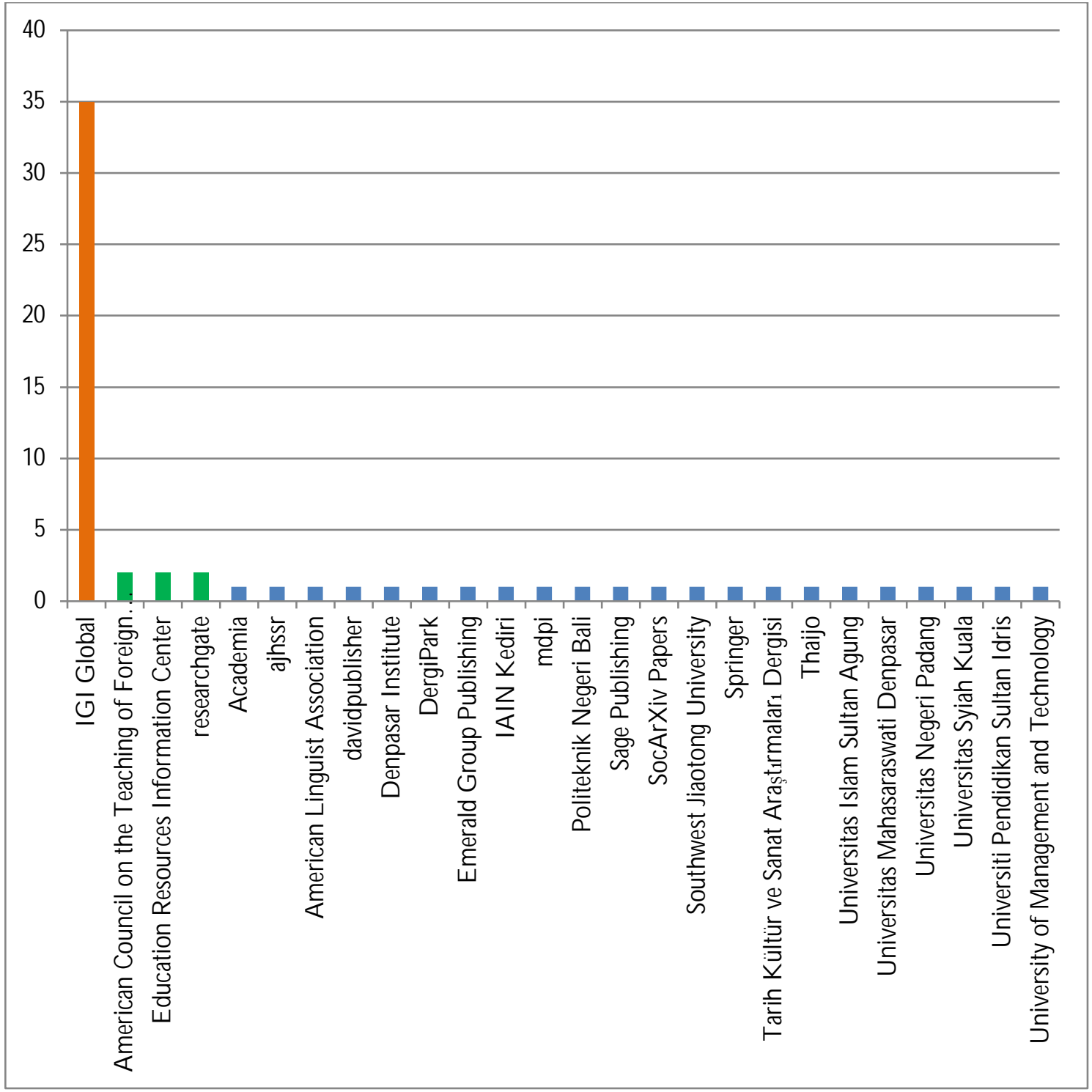

The data above also gives the following researchers who will publish the article in the same field to choose which publisher to follow.

\section{Article Distribution of English Teaching Method in Covid-19 Pandemic: Based on Joumal N ame}

The journal names published sixty-three articles of English Teaching Method in Covid-19 Pandemic in 2019 to 2020 are forty-seven journals. The leading journal, which publishes five articles, is " $\mathrm{E}$ x amining Content and L anguage Integrated L earning (C L IL ) Theories and Practioss." Then it is followed by "the International Journal of V irtual and Personal L earning E nvironments," which publishes four articles. Meanwhile, three journals are in the same position, and each publishes three articles. They are "E ngaging Immigrant Families and Promoting A cademic Sucess for E nglish L anguage L earners; ICT-Based A ssessment, M ethods, and Programs in T ertiary E ducation; U sing L iterature to T each E nglish as a Second L anguage." Furthermore, the last ranks are "Cultivating L iteracy in D iverse and Multilingual Classrooms; Foreign Language A nnals; and Innovations and Technologies for Soft Skill Development and L earning," contributing two articles. 
Table 7. List of Journal which Publishes articles of English Teaching Method in Covid-19 Pandemic

\begin{tabular}{clcc}
\hline No & \multicolumn{1}{c}{ Journal Name } & $\begin{array}{c}\text { Number of } \\
\text { Articles }\end{array}$ & Rank \\
\hline 1 & $\begin{array}{l}\text { Examining Content and Language Integrated Learning (CLIL) Theories } \\
\text { and Practices }\end{array}$ & 5 & 1 \\
\hline 2 & International Journal of Virtual and Personal Learning Environments & 4 & 2 \\
\hline 3 & $\begin{array}{l}\text { Engaging Immigrant Families and Promoting A cademic Success for } \\
\text { English Language Learners }\end{array}$ & 3 & 3 \\
\hline 4 & ICT-Based Assessment, Methods, and Programs in Tertiary Education & 3 & 3 \\
\hline 5 & Using Literature to Teach English as a Second Language & 3 & 3 \\
\hline 6 & Cultivating Literacy in Diverse and Multilingual Classrooms & 2 & 4 \\
\hline 7 & Foreign Language Annals & 2 & 4 \\
\hline 8 & Innovations and Technologies for Soft Skill Development and Learning & 2 & 4
\end{tabular}

The eight journals above are the journal that publishes more than two articles in this study where all of them are published by IG I Global as the publisher.

\section{Productivity distribution of topic articles citation of English Teaching Method in Covid-19 Pandemic}

Based on bibliometrics analysis of sixty-three articles in this study, each article's sundry number of citations shows their rank. The article was written by MD G Allo entitled "Is the online learning good in the midst of Covid-19 Pandemic? The case of EFL learners" is the leading citation. It has been cited thirty-two times. After that, the article of AEP Atmojo and A Nugroho entitled "EFL Classes Must Go Online! Teaching Activities and Challenges during COVID-19 Pandemic in Indonesia" is the second largest number of citations that have been cited twenty-three times. Below is the top ten articles cited with the most significant number of citation:

Table 8. 10 Articles Which Have Largest Citation that Identified by PoP Software

\begin{tabular}{|c|c|c|c|c|}
\hline Authors & Title of Articles & $\begin{array}{l}\text { Number } \\
\text { of Cites }\end{array}$ & $\begin{array}{l}\text { Cites per } \\
\text { Year }\end{array}$ & Rank \\
\hline MD G Allo & $\begin{array}{l}\text { Is online learning good during the Covid-19 } \\
\text { Pandemic? The case of EFL learners }\end{array}$ & 32 & 32.00 & 1 \\
\hline $\begin{array}{l}\text { AEP A tmojo, A } \\
\text { Nugroho }\end{array}$ & $\begin{array}{l}\text { EFL Classes Must G o O nline! Teaching } \\
\text { Activities and Challenges during CO VID - } 19 \\
\text { Pandemic in Indonesia }\end{array}$ & 23 & 23.00 & 2 \\
\hline $\begin{array}{l}\text { I Kostka, HW } \\
\text { Marshall }\end{array}$ & $\begin{array}{l}\text { Flipped learning in TESO L: Past, present, and } \\
\text { future }\end{array}$ & 10 & 10.00 & 3 \\
\hline $\begin{array}{l}\text { X Z hu, B Chen, } \\
\text { RM Avadhanam, H } \\
\text { Shui... }\end{array}$ & $\begin{array}{l}\text { Reading and connecting: using social annotation } \\
\text { in online classes }\end{array}$ & 8 & 8.00 & 4 \\
\hline $\begin{array}{l}\text { AH Fansury, R } \\
\text { Januarty, S Ali Wira } \\
\text { Rahman }\end{array}$ & $\begin{array}{l}\text { Digital content for millennial generations: } \\
\text { Teaching the English foreign language learner } \\
\text { on COVID-19 pandemic }\end{array}$ & 6 & 6.00 & 5 \\
\hline $\begin{array}{l}\text { ASN Agung, MW } \\
\text { Surtikanti, CA } \\
\text { Quinones }\end{array}$ & $\begin{array}{l}\text { Students' Perception of Online Learning during } \\
\text { COVID-19 Pandemic: A Case Study on the } \\
\text { English Students of STKIP Pamane Talino }\end{array}$ & 6 & 6.00 & 5 \\
\hline $\begin{array}{l}\text { FM Amin, H } \\
\text { Sundari }\end{array}$ & $\begin{array}{l}\text { EFL students' preferences on digital platforms } \\
\text { during emergency remote teaching: Video } \\
\text { Conference, LMS, or Messenger Application? }\end{array}$ & 5 & 5.00 & 6 \\
\hline $\begin{array}{l}\text { SK Shahzad, J } \\
\text { Hussain, N Sadaf, } \\
\text { S Sarwat... }\end{array}$ & $\begin{array}{l}\text { Impact of Virtual Teaching on ESL Learners' } \\
\text { Attitudes under COVID-19 Circumstances at } \\
\text { Post G raduate Level in Pakistan. }\end{array}$ & 4 & 4.00 & 7 \\
\hline
\end{tabular}




\begin{tabular}{llccc}
\hline \multicolumn{1}{c}{ Authors } & \multicolumn{1}{c}{ Title of Articles } & $\begin{array}{c}\text { Number } \\
\text { of Cites }\end{array}$ & $\begin{array}{c}\text { Cites per } \\
\text { Y ear }\end{array}$ & Rank \\
\hline $\begin{array}{l}\text { AA Yassin, NA } \\
\text { Razak, NRM }\end{array}$ & $\begin{array}{l}\text { Investigating the Need for Computer-Assisted } \\
\text { Cooperative Learning to Improve Reading } \\
\text { Maasum }\end{array}$ & 4 & 4.00 & 7 \\
& $\begin{array}{l}\text { Skills Among Yemeni University EFL Students: } \\
\text { A Needs Analysis Study }\end{array}$ & & & \\
\hline $\begin{array}{ll}\text { DAL Tan, BC Lee, } \\
\text { M Ganapathy... }\end{array}$ & $\begin{array}{l}\text { Language Learning in the 21st Century: } \\
\text { Malaysian ESL Students' Perceptions of }\end{array}$ & 4 & 4.00 & 7 \\
& Kahoot! & & & \\
\hline
\end{tabular}

\section{Mapping and Future Research Potential of English Teaching Method in Covid-19 Pandemic}

This study's mapping uses VOSViewer Software, which focuses on co-words or index-keywords that is cooccurrence written by the author. The mapping exposes the English Teaching Method's research trend in the Covid-19 pandemic from 2019 to 2020. Based on the analyzing result, the data shows thirty keywords through the co-occurrence of author keywords. The thirty keywords are divided into four clusters. The following is the figure of cluster mapping of English Teaching Method in Covid-19 Pandemic:

Figure 3. Cluster Mapping of English Teaching Method in Covid-19 Pandemic

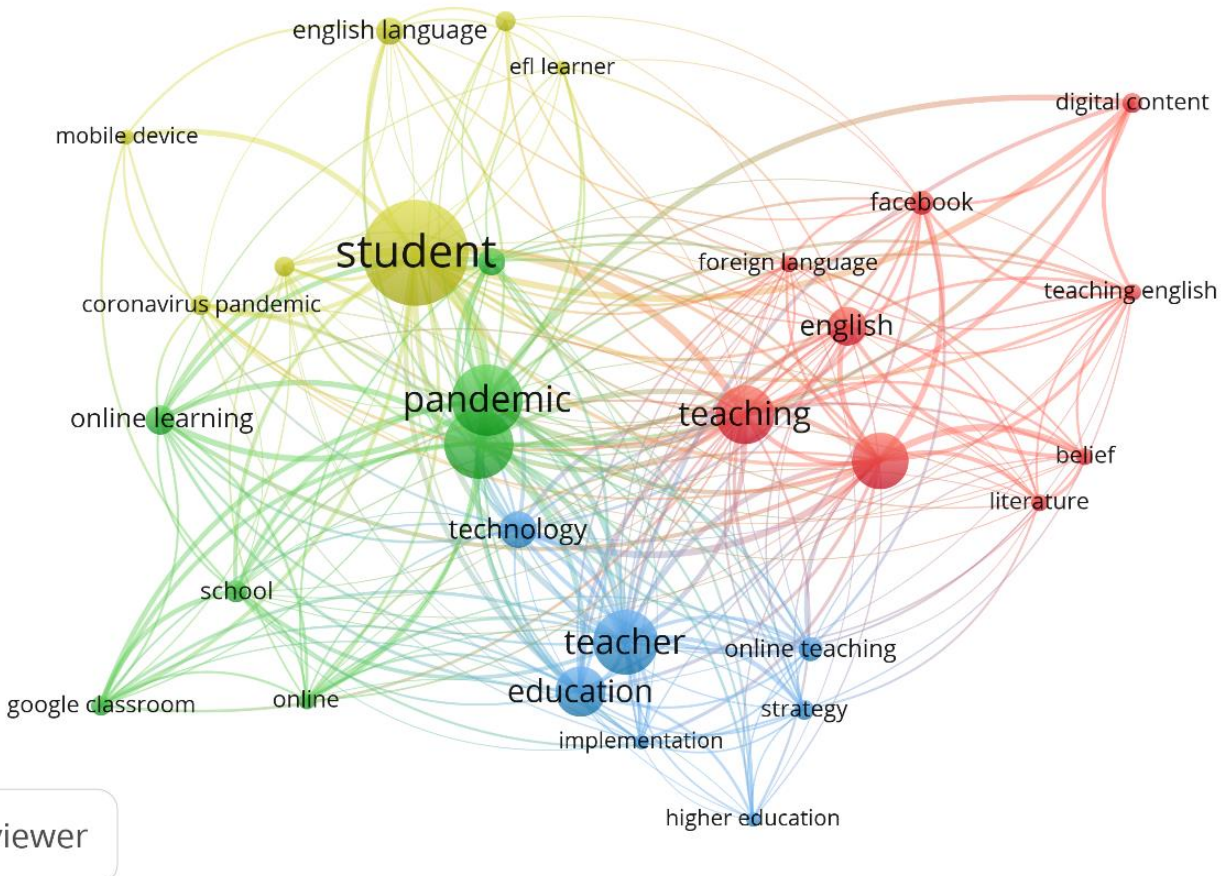

Based on cluster taxonomy, the figure shows that the research trend is in the keyword that appears the most of sixty-three articles such as student, pandemic C ovid, teacher, education, teaching, and E FL T eacher. The research trend is dominated by red color or cluster 1 . Therefore, there are four colors, which means four clusters. In cluster 1, nine items are obtained as keywords such as Belief, D igital Content, E FL Teacher, E nglish, Facebook, Foreign $\mathrm{L}$ anguage, L iterature, T eaching, and Teaching E nglish. Then, in cluster 2 (green color), seven items are obtained as a keyword such as Covid, G oogle Classroom, O nline, O nline L earning, Pandemic, Perception, and School. 
In cluster 3 (blue color), seven items are obtained as a keyword: $\mathrm{E}$ ducation, $\mathrm{H}$ igher $\mathrm{E}$ ducation, Implementation, 0 nline Teaching, Strategy, T eacher, and Technology. Moreover, the last is in cluster 4 (yellow color), which is obtained seven items as a keyword, such as C oronavirus P andemic, E F L L earner, E nglish L anguage, L anguage L earning, M obile D evice, Student, and V ocabulary. The following is the articles with co-occurrence keywords and the figure of density visualization:

Table 9. Articles with Co-Occurrence Keywords

\begin{tabular}{|c|c|c|}
\hline Cluster & Keywords & Articles \\
\hline Cluster 1 & Belief, digital content, EFL & (Altam, 2020; Hamzah Fansury et al., 2020; Inpeng \\
\hline (9 Items) & Teacher, English, & \& Nomnian, 2020; Khatoony \& Nezhadmehr, 2020; \\
\hline \multirow[t]{3}{*}{ Red } & Facebook, Foreign & Marshall \& Kostka, 2020; Nugroho \& \\
\hline & Language, Literature, & Mutiaraningrum, 2020; O bdalova, 2020; Rakıcıoğlu- \\
\hline & Teaching, Teaching English & Söylemez et al., 2019) \\
\hline Cluster 2 & Covid, G oogle Classroom, & (Agung \& Surtikanti, 2020; Allo, 2020; Altam, 2020; \\
\hline (7 Items) & O nline, O nline Learning, & Amin \& Sundari, 2020; Atmojo \& Nugroho, 2020; \\
\hline \multirow[t]{8}{*}{ G reen } & Pandemic, Perception, & Bagus \& Mantra, 2020; Fuentes Hernández et al., \\
\hline & School & 2020; Hamzah Fansury et al., 2020; Inpeng \& \\
\hline & & Nomnian, 2020; Jones, 2020; Karataş \& Tuncer, \\
\hline & & 2020; K hatoony \& Nezhadmehr, 2020; Knight, 2020; \\
\hline & & Kohnke \& Moorhouse, 2020; Marshall \& Kostka, \\
\hline & & 2020; O kmawati, 2020; Shahzad et al., 2020; Y ounesi, \\
\hline & & 2020; Zhu et al., 2020)(Amin \& Sundari, 2020; \\
\hline & & Amponsah \& van Wyk, 2020; O kmawati, 2020) \\
\hline \multirow{10}{*}{$\begin{array}{l}\text { Cluster } 3 \\
\text { (7 Items) } \\
\text { Blue }\end{array}$} & Education, Higher & (Agung \& Surtikanti, 2020; Amin \& Sundari, 2020; \\
\hline & Education, & A tmojo \& Nugroho, 2020; Fuentes Hernández et al., \\
\hline & Implementation, O nline & 2020; Hasnine et al., 2020; Inpeng \& Nomnian, 2020; \\
\hline & Teaching, Strategy, teacher, & Jones, 2020; Karataş \& Tuncer, 2020; Khatoony \& \\
\hline & technology & Nezhadmehr, 2020; Kohnke \& Moorhouse, 2020; \\
\hline & & Marshall \& Kostka, 2020; Ng et al., 2020; Nugroho \\
\hline & & \& Mutiaraningrum, 2020; O kmawati, 2020; Pavón- \\
\hline & & Vázquez, 2020; Pinto-Llorente, 2020; ŞENER et al., \\
\hline & & 2020; Shahzad et al., 2020; Tan et al., 2019; Widiastuti \\
\hline & & $\begin{array}{l}\text { et al., 2020; YANG Xiao \& HUO Ran, 2020; Zhu et } \\
\text { al., 2020) }\end{array}$ \\
\hline \multirow{6}{*}{$\begin{array}{l}\text { Cluster } 4 \\
\text { (7 Items) } \\
\text { Yellow }\end{array}$} & Coronavirus pandemic, & (Al-K hresheh \& Al-Ruwaili, 2020; Allo, 2020; Altam, \\
\hline & EFL Learner, English & 2020; Amin \& Sundari, 2020; Bagus \& Mantra, 2020; \\
\hline & Language, Language & Fuentes Hernández et al., 2020; Hasnine et al., 2020; \\
\hline & Learning, Mobile D evice, & Hijazi \& AlNatour, 2020; Kaïd \& Touhami, 2020; \\
\hline & Student, Vocabulary & Khatoony \& Nezhadmehr, 2020; Murcia, 2002; Ng \\
\hline & & $\begin{array}{l}\text { et al., 2020; O bdalova, 2020; Pham, 2019; Tan et al., } \\
\text { 2019; Widiastuti et al., 2020) }\end{array}$ \\
\hline
\end{tabular}


Figure 4. D ensity visualization of English Teaching Method in Covid-19 Pandemic Mapping

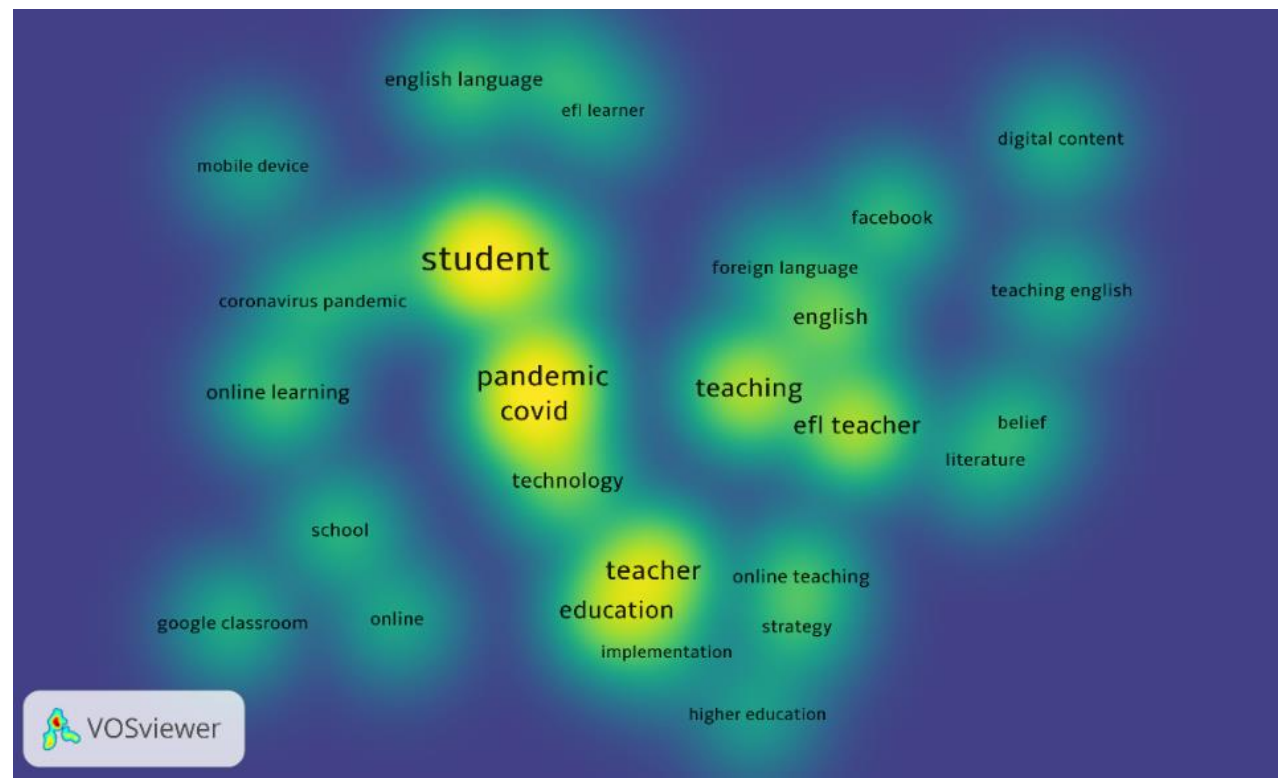

The distinct color shows that many researchers from the data above have conducted the research area of it. It means that the research on the following topic has less potential to conduct. Besides, the opaque colors show that the researchers rarely use the research area. It shows that they can be developed by the next researcher, especially in clusters 3 and cluster 4.

In addition, this study analyzes the English teaching method available in the Google Scholar database, where the researches in the same area are contained. Future researchers may conduct other topics such as English teaching media in the Covid-19 Pandemic as shown in the VO Sviewer before.

\section{CONCLUSION}

This study analyzes sixty-three articles of English Teaching Method in Covid-19 Pandemic by using four Softwares: Publish or Perish (PoP), Microsoft Excel, Mendeley, and VOSViewer. The data was found after filtering 989 articles obtained by searching through Publish or Perish (PoP) Software on the G oogle Scholar database using the keyword "English Teaching Method in Covid-19 Pandemic" in 2019-2020. This study analyzes sixty-three articles based on quartile in SCImago, Publication Y ear, Publisher, Country of Publisher, Journal name, and citations. Then the analysis continued by using VO SViewer to map the keywords that many researchers used. Hence, the research trend is in the keyword that appears the most of sixty-three articles such as student, pandemic Covid, teacher, education, teaching, and E FL Teacher. Besides, it gives the next researcher the information to conduct another English Teaching Media in the Covid-19 pandemic. This study has two weaknesses. The first is that personal touch cannot be avoided, which can be an error of analysis. The second is limited keywords available in the G oogle scholar database as the primary source of this study. The following study can use another database to get more quality data, such as a database of Scopus, web of science, PubMed, Microsoft A cademic, Crossref, etc. 


\section{REFERENCES}

Agung, A. S. N., \& Surtikanti, M. W. (2020). Students' Perception of O nline Learning during COVID-19 Pandemic: A Case Study on the English Students of STKIP Pamane Talino. SO SH U M : Jurnal Sosial D an H umaniora, 10(2), 225- 235. https:/ / doi.org/ 10.31940/ soshum.v10i2.1316 [G oogle Search] [G oogle Scholar] [Google Books] [Publisher website]

Al-Khresheh, M., \& Al-Ruwaili, S. F. (2020). An Exploratory Study into Vocabulary Learning Strategies Used by Saudi EFL learners. Journal of H istory C ulture and A rt Research, 9(2), 288-302.

https:/ / doi.org/ 10.7596/ taksad.v9i2.2616 [G oogle Search] [G oogle Scholar] [G oogle Books] [Publisher website]

A llo, M . D . G . (2020). Is online learning good in the midst of the Covid-19 Pandemic? The case of E F L learners. Jurnal Sinestesia, 10(1), 1-10. [G oogle Search] [G oogle Scholar] [G oogle Books]

A ltam, S. (2020). Influence of social media on E FL Y emeni learners in Indian U niversities during Covid-19 Pandemic. L inguistics and Culture Review, 4(1), 35-47. [G oogle Search] [Google Scholar] [G oogle Books]

Amin, F. M., \& Sundari, H. (2020). EFL students' preferences on digital platforms during emergency remote teaching: Video Conference, LMS, or Messenger Application?. Studies in E nglish L anguage and E ducation, 7(2), 362-378. https:/ / doi.org/ 10.24815/ siele.v7i2.16929 [G oogle Search] [G oogle Scholar] [G oogle Books] [Publisher website]

Amponsah, S., \& van Wyk, M. M. (2020). STAD Cooperative Pedagogy in Teaching English First Additional Language in K waZ ulu-Natal Secondary Schools. International Journal of Teacher E ducation and Professional D evelopment, 3(2), 47-64. https:/ / doi.org/ 10.4018/ ijtepd.2020070104 [G oogle Search] [G oogle Scholar] [Google Books] [Publisher website]

Ardito, L., Scuotto, V., Del Giudice, M., \& Petruzzelli, A. M. (2019). A bibliometric analysis of research on Big D ata analytics for business and management. M anagement D ecision, 57(8), 1993- 2009. https:/ / doi.org/ 10.1108/ md-07-2018-0754 [G oogle Search] [G oogle Scholar] [G oogle Books] [Publisher website]

Atmojo, A. E. P., \& Nugroho, A. (2020). EFL Classes Must G o O nline! Teaching Activities and Challenges during COVID -19 Pandemic in Indonesia. Register Journal, 13(1), 49- 76. https:/ / doi.org/ 10.18326/ rgt.v13i1.49-76 [G oogle Search] [G oogle Scholar] [G oogle Books] [Publisher website]

Bagus, I., \& Mantra, N. (2020). COV ID-19 TE RMIN OL OGIE S: THE EX TEN T OF STUDENT 'S V OCA BULARY A CQUISITION DURING LEARNING FROM HOME. 2(1), 41-47. [Google Search] [G oogle Scholar] [Google Books]

Basuki, S. (2002). Pemetaan Ilmu Pengetahuan. Kumpulan Makalah Kursus Bibliometrika. [G oogle Search] [G oogle Scholar] [Google Books]

E disherashvili, N . (2014). Communicative L anguage T eaching in G eorgia: F rom Theory to Practice. L OT . [G oogle Search] [G oogle Scholar] [Google Books]

Ellegaard, O . (2018). The application of bibliometric analysis: disciplinary and user aspects. Scientometrics, 116(1), 181-202. https:/ / doi.org/ 10.1007/ s11192-018-2765-z [G oogle Search] [G oogle Scholar] [G oogle Books] [Publisher website]

Fansury, A. H., Januarty, R., Rahman, A. W., \& Syawal. (2020). Digital Content for Millennial G enerations: Teaching the English Foreign Language Learner on COVID -19 Pandemic. Journal of Southwest Jiaotong U niversity, 55(3). https:/ / doi.org/ 10.35741/ issn.0258-2724.55.3.40 [G oogle Search] [G oogle Scholar] [Google Books] [Publisher website] 
F uentes H ernández, S. S., N aren, A ., \& F lórez, S. (2020). 0 nline Teaching during C ovid-19: H ow to M aintain Students M otivated in an E FL Class. O nline) Journal H omepage, 6(2), 2409-109. [G oogle Search] [G oogle Scholar] [Google Books]

Hasnine, M. N., O gata, H., Akçapınar, G ., Mouri, K., \& Kaneko, K. (2020). Closing the Experiential Learning Loops Using Learning Analytics Cycle. International Journal of D istance E ducation Technologies, 18(3), 7898. https:/ / doi.org/ 10.4018/ ijdet.2020070105 [G oogle Search] [G oogle Scholar] [G oogle Books] [Publisher website]

Hijazi, D . A., \& AlNatour, A. S. (2020). The Effect of Using Blended Learning Method on Students' Achievement in English and Their Motivation Towards Learning It. International Journal of $\mathrm{V}$ irtual and Personal L earning E nvironments, 10(2), 83- 96. https:/ / doi.org/ 10.4018/ ijvple.2020070106 [G oogle Search] [G oogle Scholar] [Google Books] [Publisher website]

https:/ / www.who.int/ director-general/ speeches/ detail/ who-director-general-s-opening-remark s-at-the media-briefing-on-ovid-19--11-march-2020 accessed on D exember 22, 2020. [G oogle Search] [G oogle Scholar] [G oogle Books]

Inpeng, S., \& N omnian, S. (2020). The use of facebook in a TE FL program based on the track framework. LE A RN Journal: L anguage E ducation and A cquisition Research N etwork, 13(2), 369-393. [G oogle Search] [G oogle Scholar] [Google Books]

Jones, M . (2020). Technology E x penses and E ducation among U niversity E nglish L anguage T eachers. https:/ / doi.org/ 10.31235/ osfio/ 64zuj. [G oogle Search] [Google Scholar] [Google Books]

Karataş, T., \& Tuncer, H. (2020). Sustaining Language Skills D evelopment of Pre-Service EFL Teachers despite the COVID-19 Interruption: A Case of Emergency D istance Education. Sustainability, 12(19), 8188. https:/ / doi.org/ 10.3390/ su12198188 [G oogle Search] [Google Scholar] [G oogle Books] [Publisher website]

Kaïd, F., \& Touhami, I. (2020). D eveloping the EFL Learners' Interdisciplinary Thinking Through Teaching Literature. In A dvancing E ducational Research W ith E merging Technology (pp. 99-121). IG I Global. https:/ / doi.org/ 10.4018/ 978-1-7998-4670-3.ch006 [G oogle Search] [G oogle Scholar] [Google Books] [Publisher website]

Keywords : digital learning of E nglish ; E FL learners " perception ; E nglish adivities beyond dassroom; social networking sites. (n.d.). 2019, 219- 243. [G oogle Search] [G oogle Scholar] [G oogle Books]

Khatoony, S., \& N ezhadmehr, M. (2020). E FL teachers' dhallenges in integration of technology for online dassrooms during Coronavirus (COV ID -19) pandemic in Iran. A JE L P: A sian Journal of E nglish L anguage and Pedagogy, 8, 1-16. https:/ / ojs.upsi.edu.my/ index.php/ A JE L P/ artide/ view/ 3523. [G oogle Search] [G oogle Scholar] [G oogle Books]

Knight, S. W. P. (2020). Establishing professional online communities for world language educators. Foreign L anguage A nnals, 53(2), 298-305. https:/ / doi.org/ 10.1111/ flan.12458 [G oogle Search] [G oogle Scholar] [Google Books] [Publisher website]

Kohnke, L., \& Moorhouse, B. L. (2020). Facilitating Synchronous O nline Language Learning through Zoom. RE L C Journal. https:/ / doi.org/ 10.1177/ 0033688220937235 [G oogle Search] [G oogle Scholar] [G oogle Books] [Publisher website]

Mahesh D eelip, K., Salman Faruk, K., Tarachand G adilohar, H ., \& Prabhakar Baviskar, D . (2016). M odern A pproaches and $\mathrm{M}$ ethods in Teaching $\mathrm{E}$ nglish $\mathrm{L}$ anguage. International Journal of Research and Innovation, 02(03), 6- 13. [G oogle Search] [G oogle Scholar] [G oogle Books]

Marshall, H . W ., \& Kostk a, I. (2020). F ostering teaching presenœ through the synchronous online flipped learning approach. T esl-E j, 24(2), 1-14. [G oogle Search] [G oogle Scholar] [Google Books]

Munzaki, D. F., Suadah, L., \& Risdaneva, R. (2017). TEACHING METHOD S USED BY STUDENTS OF DEPARTMENT OF ENGLISH LANGUAGE EDUCATION OF UIN AR-RANIRY IN 
TEACHING ENG LISH AT ENG LISH COURSE. E nglish: Journal of L anguage, E ducation, and H umanities, 4(1), 10-26. https:/ / doi.org/ 10.22373/ ej.v4i1.1023 [G oogle Search] [G oogle Scholar] [Google Books] [Publisher website]

M urcia, M. C . (2002). Teaching E nglish as a Second or F oreign L anguage (3rd E ditio). MA : H einle \& H einle. [Google Search] [G oogle Scholar] [Google Books]

Ng, S. F., Azlan, M. A. K., Kamal, A. N. A., \& Manion, A. (2020). A quasi-experiment on using guided mobile learning interventions in ESL classrooms: Time use and academic performance. E ducation and Information Technologies, 25(6), 4699-4719. https:/ / doi.org/ 10.1007/ s10639-020-10191-7 [G oogle Search] [G oogle Scholar] [Google Books] [Publisher website]

Nobre, G. C., \& Tavares, E. (2017). Scientific literature analysis on big data and internet of things applications on circular economy: a bibliometric study. Scientometrics, 111(1), 463- 492. https:/ / doi.org/ 10.1007/ s11192-017-2281-6 [G oogle Search] [G oogle Scholar] [G oogle Books] [Publisher website]

Nugroho, A., \& Mutiaraningrum, I. (2020). EFL teachers' beliefs and practices about digital learning of English. E duL ite: Journal of E nglish E ducation, L iterature and C ulture, 5(2), 304-321. https:/ / doi.org/ 10.30659/ e.5.2.304-321 [G oogle Search] [G oogle Scholar] [G oogle Books] [Publisher website]

Obdalova, O . A. (2020). Content-Based EFL Teaching to Undergraduate Science Students. A dvancing E ducational Research W ith E merging T echnology, 208- 225, 208-225. https:/ / doi.org/ 10.4018/ 978-1-79983266-9.ch012 [G oogle Search] [G oogle Scholar] [G oogle Books] [Publisher website]

O kmawati, M. (2020). The Use of G oogle Classroom during Pandemic. Journal of E nglish L anguage Teaching, 9(2), 438. https:/ / doi.org/ 10.24036/ jelt.v9i2.109293 [G oogle Search] [G oogle Scholar] [G oogle Books] [Publisher website]

Patel, M .F., Jain, P. M . (2008). E nglish L anguage Teaching (1st E ditio). Sunrise Publishers \& D istributors. [Google Search] [G oogle Scholar] [Google Books]

Pavón-Vázquez, V. (2020). Implementing English-taught Programmes in Higher Education in Spain. In A dvancing E ducational Research W ith E merging Technology (pp. 138-150). IGI G lobal. https:/ / doi.org/ 10.4018/ 978-1-7998-3266-9.ch008 [G oogle Search] [G oogle Scholar] [Google Books] [Publisher website]

Pham, D . H. (2019). Nominalization Versus Clause Usage in CALL Technology-Mediated Acquisition of EFL Learners' Writing Skills. International Journal of $\mathrm{V}$ irtual and Personal L earning E nvironments, 9(2), 7286. https:/ / doi.org/ 10.4018/ ijvple.2019070105 [G oogle Search] [G oogle Scholar] [G oogle Books] [Publisher website]

Pinto-Llorente, A. M. (2020). A Digital Ecosystem for Teaching-Leaming English in Higher Education. In A dvancing E ducational Research W ith E merging Technology (pp. 257-276). IGI G lobal. https:/ / doi.org/ 10.4018/ 978-1-7998-3062-7.ch013 [G oogle Search] [G oogle Scholar] [Google Books] [Publisher website]

Rakıcıoğlu-Söylemez, A., Söylemez, A. S., \& Y eşilbursa, A. (2019). Exploring Prospective EFL Teachers' Beliefs About Teachers and Teaching Through Metaphor Analysis. In Q uality M anagement Implementation in H igher E ducation (pp. 131-147). IGI Global. https:/ / doi.org/ 10.4018/ 978-1-52258583-1.ch008 [G oogle Search] [G oogle Scholar] [G oogle Books] [Publisher website]

Shahzad, S. K., Hussain, J., Sadaf, N., Sarwat, S., G hani, U., \& Saleem, R. (2020). Impact of Virtual Teaching on ESL Learners' Attitudes under Covid-19 Circumstances at Post G raduate Level in Pakistan. E nglish L anguage T eaching, 13(9), p1. https:/ / doi.org/ 10.5539/ elt.v13n9p1 [G oogle Search] [G oogle Scholar] [G oogle Books] [Publisher website] 
Tan, D . A. L., Lee, B. C., G anapathy, M., \& Kasuma, S. A. A. (2019). Language Learning in the 21st Century. International Journal of $V$ irtual and Personal L earning E nvironments, 9(2), 55- 71. https:/ / doi.org/ 10.4018/ ijvple.2019070104 [G oogle Search] [G oogle Scholar] [G oogle Books] [Publisher website]

W idiastuti, I. A . M . S., M antra, I. B. N ., \& van E ngelen, B. (2020). M obile Internet-Based L earning To C ultivate Students ' Speaking Skill D uring C oronavirus Pandemic. International Journal of A pplied Science and Sustainable D evelopment, 2(1), 6-10. https:/ / ejournal.unmas.acid/ index.php/ IJA SSD / issue/ view/ 65\%0A https:/ / e journal.unmas.acid/ index .php/ IJA SSD / artide/ view/ 739. [G oogle Search] [G oogle Scholar] [G oogle Books]

Xiao, Y., \& Ran, H. (2020). Effects of O nline Teaching on Student Autonomous Learning with U-MO OCs: A Case Study of Business English and Communication. Journal of L iterature and A rt Studies, 10(4), 307312. https:/ / doi.org/ 10.17265/ 2159-5836/ 2020.04.006 [G oogle Search] [G oogle Scholar] [G oogle Books] [Publisher website]

Y ildizlar, M . (2013). 0 gretim Ilke ve Y ontemleri (4th editio). A nkara: Pegem A kademi. [G oogle Search] [G oogle Scholar] [Google Books]

Y ounesi, M . (2020). E nglish language teaching through the Internet at Post C OV ID -19 age in India: V iews and A ttitudes. 7(September), 870- 875. https:/ / doi.org/ 10.1729/ Journal.24464. [G oogle Search] [G oogle Scholar] [G oo gle Books]

Yu, D ., Xu, Z., \& Antuchevičienè, J. (2019). BIBLIO METRIC ANALY SIS OF THE JO URNAL OF CIVIL ENGINEERING AND MANAGEMENT BETWEEN 2008 AND 2018. JOURNA L OF CIV IL

EN GINEERING A N D MAN A GEMEN T, 25(5), 402-410. https:/ / doi.org/ 10.3846/ jcem.2019.9925 [G oogle Search] [G oogle Scholar] [G oogle Books] [Publisher website]

Zhu, X., Chen, B., Avadhanam, R. M., Shui, H., \& Zhang, R. Z. (2020). Reading and connecting: using social annotation in online classes. Information and L earning Science, 121(5/ 6), 261-271. https:/ / doi.org/ 10.1108/ ils-04-2020-0117 [Google Search] [G oogle Scholar] [G oogle Books] [Publisher website]

Şener, B., Ertem, I. S., \& Meç, A. (2020). Online Teaching Experiences of ELT Instructors. Journal of E ducational Technology and 0 nline L earning, 3(3), 340-362. https:/ / doi.org/ 10.31681/ jetol.770418 [G oogle Search] [Google Scholar] [G oogle Books] [Publisher website] 